\section{Implications of genetic variability of Trypanosoma cruzi for the pathogenesis of Chagas disease}

\author{
Implicações da variabilidade genética do \\ Trypanosoma cruzi na patogênese da \\ doença de Chagas
}

\footnotetext{
${ }^{1}$ Departamento de Biologia, Universidade Estadual

Paulista, São José do

Rio Preto, Brasil.

Correspondence

A. E. Silva

Departamento de Biologia,

Universidade Estadual

Paulista.

Rua Cristóvão Colombo 2265,

São José do Rio Preto, SP

15054-000, Brasil.

anabete@ibilce.unesp.br
}

\begin{abstract}
Trypanosoma cruzi, the etiological agent of Chagas disease, presents a high degree of intraspecific genetic variability, with possible implications for the clinical forms of the disease, like the development of cardiopathy, megaesophagus, and megacolon, alone or in combination. This tissue tropism involved in the pathogenesis of Chagas disease has still not been totally elucidated. Thus, the current review approaches key aspects of $\mathrm{T}$. cruzi genetic diversity, the clinical forms of Chagas disease, and the infection of the host cell by the parasite and the immune response. Other aspects discussed here include the release of immunosuppressive factors by the parasite, acting in the host's immune response pathways; host cell apoptosis inhibition; the pathogenesis of chagasic megaesophagus, which can be related to host-parasite interaction; and finally the association between megaesophagus and increased risk for the development of squamous-cell esophageal carcinoma. However, despite great advances in the understanding of this disease, it is still not possible to establish the true relationship between the parasite's genetic variability and the clinical form of Chagas disease.
\end{abstract}

Esophageal Achalasia; Trypanosoma cruzi; Variation (Genetics); Chagas Disease
Fernanda da Silva Manoel-Caetano 1 Ana Elizabete Silva 1

\section{Biology of Trypanosoma cruzi and Chagas disease}

Trypanosoma cruzi, a flagellate protozoan of the Kinetoplastida order, Trypanosomatidae family, is the etiological agent of Chagas disease, a frequent anthropozoonosis in Latin America 1,2.

The parasite's life cycle alternates between vertebrates and insects, with different principal developmental stages in each host, with infective replicative epimastigotes (stage with kinetoplast and flagellar pouch in the anterior position of the nucleus) and metacyclic trypomastigotes (kinetoplast in the extremity posterior to the nucleus) in the hematophagous vector, replicative intracellular amastigotes (rounded form with short inconspicuous flagellum), and bloodstream trypomastigotes in the mammalian host 1.

Naturally acquired T. cruzi infections are initiated in the dermal layers or conjunctival mucosa by infective metacyclic trypomastigote forms that are transmitted by an infected hematophagous triatomine vector 3 and are thereby transformed into amastigotes with the capacity to multiply by simple binary division. Next, they differentiate into trypomastigotes that are released by the host cell into the interstitium and reach the bloodstream and are thus able to invade cells from any tissue to produce a new cycle or be destroyed by host immune mechanisms 2 . For example, the slender forms are lysed during the acute phase of the disease by the comple- 
ment system present in the host cell plasma membrane 1 .

The potential vectors for $T$. cruzi cover more than 130 species of triatomine insects from the Reduviidae family, five of which are epidemiologically more significant: Triatoma infestans, Triatoma brasiliensis, Triatoma dimidiata, Rhodnius prolixus, and Panstrongylus megistus 4.

In addition to triatomines, the parasite can be transmitted in other ways, for example by blood transfusion, which is no longer an important route in the Latin American countries that have established effective routine serological control in blood centers 5,6. Transmission from mothers with Chagas disease to their fetuses has also been reported, with the incidence varying from less than $1 \%$ to $10 \%$, even outside endemic areas 5 . Outbreaks of acute Chagas disease can also occur due to oral transmission through contaminated foodstuffs like tea, sugar cane juice, or açaí juice, described in the Amazon Region 7 and more recently in the Brazilian States of Santa Catarina 6 and Ceará ${ }^{8}$. Although such events are worrisome, they are extremely rare and bear no relationship to the current situation with the control of vector-borne transmission by Triatoma infestans, the principal vector species in Brazil 6 .

Recently, Cortez et al. ${ }^{9}$ observed that the gp82 adhesion molecule expressed by $T$. cruzi is related to oral infection in experimentally infected mice. Thus, the molecule could also be associated with outbreaks due to oral transmission in humans. The factor accounting for the high infectivity of ingested parasites have still not been fully elucidated 10 , but the occurrence of severe cases of infection leading to death in many infected individuals $6,7,8,11$ indicates a high pathogenicity of the parasites and their capacity to penetrate the gastric mucosa, despite the action of acid gastric contents 10 . It has been demonstrated that digestion of the gp90 molecule specific to the metacyclic trypomastigote stage by pepsin increases the infectivity of HeLa cells due to the corresponding increase in gp82 9 .

Chagas disease currently affects some 16 to 18 million individuals, concentrated in the poorest rural and urban areas of Latin America and representing one of the most serious public health problems in the region 2,12,13, where more than 100 million people are exposed to infection 14 . Brazil (principally the Northeast, Southeast, and South) accounts for a major portion of these millions of infected individuals 15 .

Chagas disease presents a variable clinical course, including an acute or initial phase which can be asymptomatic, oligosymptomatic, or symptomatic, with fever, adenomegaly, unilateral conjunctivitis (Romaña's sign), miocardi- tis, and meningoencephalitis; the initial phase can be fatal in up to $10 \%$ of severe cases, with higher mortality in children under three years of age due to meningoencephalitis 14 . The chronic phase represents a latency period of 10-15 years, referred to as the indeterminate form 14 , after which some $27 \%$ of infected individuals develop cardiac symptoms that can lead to sudden death, $6 \%$ develop digestive damage, and $3 \%$ can present involvement of the peripheral nervous system 13. Genetic variability of both the parasite and host can influence the clinical forma of Chagas disease 16 .

In Brazil, $50 \%$ of $60 \%$ of individuals with Chagas disease present the indeterminate chronic phase. Some $2 \%$ of $4 \%$ these per year progress to the clinically defined severe chronic phase, with cardiac or gastrointestinal involvement, with progressive disease and more frequently involving males beginning in their thirties or fourties 12 .

In endemic areas, $15 \%$ to $20 \%$ of chronic Chagas disease carriers develop digestive tract motility, secretion, and absorption disorders, especially in the esophagus and colon. Such alterations appear first with slow transit and difficulty in emptying, followed by increased caliber of the affected organ and greater difficulty in emptying, characterizing the presence of megaesophagus (grades I to IV) or megacolon 5. Involvement of the enteric nervous system appears to be an essential element and generally precedes the alterations in the motility of these organs 5,17 .

The mechanisms determining the clinical forms of the disease (cardiac or digestive) have not been totally elucidated, but extensive research points to the importance of genetic diversity in the parasite and host immune response. The current review covers several of these aspects.

\section{Genetic diversity of Trypanosoma cruzi}

The geographic distribution of triatomines and vertebrate hosts associated with hematophagous insects' preference for specific blood sources define two T. cruzi transmission cycles: a wild cycle involving different triatomines and wild animals and a domiciliary/peridomiciliary cycle in which domestic animals and humans can act as reservoirs 18 .

Parasite clone populations are obtained from triatomine vectors or mammalian hosts. Patients in endemic areas are probably infected by multiple contacts with different triatomines, and the latter in turn can feed on the blood of various infected individuals, thus leading to the formation of multiclonal populations in hosts and vectors 16. Such populations differ in terms of their 
genetic and biological characteristics and their behavior in the vertebrate host 19 .

The genetic variability of $T$. cruzi populations has been demonstrated repeatedly, based mainly on enzyme electrophoresis patterns (zymograms) and variation in the kinetoplast DNA (kDNA) 20.

Systematic enzymatic studies were initiated by Miles et al. 21 in T. cruzi samples isolated from different hosts in various regions of Brazil. Using electrophoresis methods, the authors described three classes of parasites, distinguished on the basis of specific patterns for a group of enzymes. These classes or "enzymatic lineages" were designated zymodemes (Z1, Z2, and Z3), each including all the parasites with identical electrophoresis patterns for the target enzymes. Epidemiological studies demonstrated that $\mathrm{Z} 1$ and $\mathrm{Z} 3$ were associated with the wild cycle and $\mathrm{Z} 2$ with the domiciliary cycle 22 .

Later, Tibayrenc et al. 23 demonstrated the existence of marked polymorphism in T. cruzi isolated from different hosts from other regions of South America. By studying 15 enzyme-coding gene loci in T. cruzi clones isolated from different geographic areas, they observed much greater diversity and proposed 43 genotypes. This group of researchers also suggested the possibility of a clonal structure for the T. cruzi lineages based on the existence of clones without sexual interactions separated by a long evolutionary process. Thus, T. cruzi lineages are natural clones, with natural selection favoring only certain types of genetic patterns or combinations, and may result in a limited number of groups of isoenzymes represented by three principal clones 24 .

The hypothesis of a correlation between the biological and phylogenetic variability of T. cruzi was confirmed by Revollo et al. 25 using various in vitro parameters, like MLEE (multilocus enzyme electrophoresis) and RAPD (randomly amplified polymorphic DNA), based on the genetic distances. Thus, the biological types (biodemes) were correlated with the zymodemes (Z1, Z2, and Z3) described by Miles et al. 22, with type II biodeme corresponding to Z2 and type III to Z1 19 . The exception was type I, which presented a peculiar electrophoretic profile, not described previously 26 and was subsequently identified as Z2b.

The identification of nuclear DNA markers with very low evolutionary rates, like the RNAr 24S $\$$ \#945 gene and the intergenic region of genes with miniexons helped established the existence of two principal phylogenetic lineages within the T. cruzi taxon 27. These lineages were name by an expert committee based on biochemical and/or genetic evidence, as T. cruzi group I and T. cruzi group II. T. cruzi group I corresponds to $\mathrm{Z} 1$ and $T$. cruzi II to $\mathrm{Z2} 28$. Isolates belonging to $\mathrm{Z} 3$ were not included in this classification. Subsequent application of the RAPD, MLEE, and karyotyping techniques indicated that group II was subdivided into discrete typing units (DTUs) displaying distinct geographic and ecological variations, with two groups found principally in the wild environment and three limited to the domiciliary transmission cycle 29,30. Further application of molecular techniques like RAPD and SSR-PCR (simple sequence repeat anchored primer-PCR) led to high homogeneity of T. cruzi lineages in chronic patients from different endemic areas of Brazil, thus suggesting that human hosts select specific varieties of the parasite clones from what are probably mixed infective populations 31 .

These findings were recently confirmed by the RAPD technique based on T. cruzi isolates from patients with the cardiac and indeterminate forms of chronic Chagas disease, with low genetic variability observed between the parasites analyzed, thus clearly indicating the presence of a genetic group that was well correlated with $T$. cruzi populations 32 .

Analysis of the parasite population structure based on the discovery of microsatellites in $T$. cruzi has shown that the percentage of multiclonal populations decreases progressively when comparing wild-cycle clones with those isolated from humans, thus reinforcing that human hosts select specific varieties of $T$. cruzi clones from mixed infective populations 33 , due to the immune response. Such processes may be related to the reduction in genetic complexity of T. cruzi lineages isolated from chronic patients. According to another explanation, at the precise moment the parasite is isolated in the host, one population might predominate over the others, considering that in the parasite's life cycle, blood trypomastigotes are not released according to a circadian rhythm 32 .

The marked variability among chronic patients in the tropism of preferentially infected tissue (cardiac or digestive) and the parasite's pathogenicity evokes the issue of whether the differential pathogenesis of the disease reflects the distinction between T. cruzi lineages 20 .

Epidemiological studies have shown evidence suggestive of an association between $T$. cruzi group II and placental mammals and particularly human infection. This fact was observed in distant geographic areas like Brazil and Bolivia, where the majority of Chagas disease carriers were in the chronic phase and with infections limited to T. cruzi II 34,35. Additionally, among those with acute Chagas disease, a small propor- 
tion was infected with T. cruzi I and/or presented T. cruzi I/II co-infections 35 .

In Brazil, T. cruzi I appears to be found preferentially in the wild cycle of Chagas disease transmission, while T. cruzi II is heavily associated with the domiciliary cycle 36 . This was confirmed recently by the demonstration of $T$. cruzi group II parasites infecting human tissues (esophagus, heart, and colon) in 25 patients with the cardiac or gastrointestinal forms of the disease residing in various cities in the State of Minas Gerais 37 . Meanwhile, epidemiological evidence suggests that cases of chronic human infection in the north of South America and in Central America may be due to T. cruzi group I 38 .

Lauria-Pires et al. 39 , using isoenzyme assays and RFLP (restriction fragment length polymorphisms), observed mixed infections in both a patient with the cardiac form of Chagas disease and another with megaesophagus. The patient with megaesophagus showed at least three different populations of the parasite, demonstrating that a Chagas disease patient can be infected with genetically diverse populations of T. cruzi.

Although the isoenzymatic variability of $T$. cruzi populations has allowed the identification of three principal groups of zymodemes (Z1, Z2, and Z3), it is important to note that isoenzymes are markers expressed and limited to the control of the parasite's life stage, requiring 109-1010 parasites for typing, in addition to the fact that the culture conditions allow spurious results, thus limiting the routine use of this technique 16 . Therefore, the first major stride with high-resolution techniques for studying T. cruzi genetic variability was the discovery of restriction fragment length polymorphisms in kinetoplast DNA 40.

Kinetoplast DNA (kDNA) is a plate-like structure including concatenated circular molecules called maxicircles (analogous to the mitochondrial DNA of other eukaryotes) and minicircles 41 , comprising $20-25 \%$ of the parasite's total DNA 1. Maxicircles are large molecules with few copies, containing genes for mitochondrial proteins and RNAr. Minicircles are small molecules $(1.4 \mathrm{~kb})$ with 20-25 thousand copies, associated with RNA editing. They present conserved regions and variable regions with a high mutation rate, and their sequences can differ widely between different parasite lineages 41,42 . This heterogeneity appears to be necessary to furnish sufficient genetic information for the extensive RNA editing ${ }^{42}$. Thus, kDNA appears to be essential for $T$. cruzi genetic variability 1,43 .

The first studies on $T$. cruzi DNA polymorphisms reported the typing of kDNA minicircles by the RFLP technique, revealing parasite populations with identical or very similar minicircle patterns and referred to as schizodemes (the restriction profile of a lineage) ${ }^{40}$. In the minicircles, four variable $330 \mathrm{bp}$ portions of kDNA are evaluated which evolved rapidly enough to produce differences between isolated parasites or clones, but not to the point of precluding a stable genetic identity in the lineage. Thus, each lineage and in some cases each clone in the same lineage presents a different schizodeme 40 .

Another, more sensitive method to study kDNA polymorphisms is low stringency single specific primer-PCR or LSSP-PCR 44,45, in which the $330 \mathrm{bp}$ regions of the minicircles from previously amplified kDNA function as a mold for a second PCR with a single primer specific to it, under very low stringency conditions. The primer specifically hybridizes this complementary region and nonspecifically hybridizes multiple sites within the fragment in a sequence-dependent fashion, producing a highly complex class of reaction products visualized by electrophoresis to generate "genetic signatures". For the first time, this technique, used with great success in the amplification of this region, produced a profile of the parasites present in the tissues of chronically infected patients 46,47 .

Analyses of genetic profiles obtained from the variable kDNA region showed a high degree of intraspecific variability in parasite popula tions isolated from patients with the same clinical form of the disease, independently of clinical characteristics and disease stages, with unique genetic signatures obtained for each individual patient 48 . This intense kDNA gene polymorphism may result from different factors, such as the presence of different classes of minicircle sequences for each parasite, high mutation rates in the hypervariable regions, reversible damage to kDNA sequences, or low identity between them 48 .

Despite the indication of a differential distribution of lineages in the wild and domiciliary cycles of T. cruzi transmission and Chagas disease pathogenesis, based on the current studies on the parasite's genetic diversity, it is still not possible to establish a precise association between the parasite's lineages or clones and the clinical form of the disease.

\section{Tissue tropism: parasite-host interaction and immune response activation}

In Chagas disease, the existence of different $T$. cruzi clones may help explain the occurrence of areas in which the disease shows a higher incidence of cardiac or digestive involvement than in others 49 , but other mechanisms are certainly 
at play, like those involved in the parasite-host interaction and immune response. In the various hosts, the clones join to form multiclonal populations, and some of these associations are selectively advantageous and form stable clone populations 16 .

One explanation for the correlation between specific elements in T. cruzi variability and the clinical characteristics of Chagas disease is that the parasite populations represent groups of clones that can present symbiotic relations, while competing heavily for available resources 16 . Experiments in mice have demonstrated that over the course of infection, various T. cruzi populations present different forms of blood trypomastigotes (slender, intermediate, and broad). They thus display important behavior differences between populations, with one or another type of morphology predominating ${ }^{2}$. Due to biological polymorphism, different clones in a lineage can present tropism for different tissues, becoming a determinant factor for the clinical course of Chagas disease due to the clonal repertoire of the infecting lineage and its specific tropisms. This scenario is at the center of what is referred to as the "clonal histotropic model" of Chagas disease 16.

For example, populations with predominantly slender forms are more infective to human and mouse cells, developing earlier parasitemias, yet more sensitive to circulating antibodies. Meanwhile, populations with predominantly broader and less infective forms take longer to penetrate the cells, developing later parasitemias in mice, yet more resistant to the action of antibodies, thus remaining longer in the bloodstream. Cell tropism also differs between these forms, since slender trypomastigotes preferentially infect cells from the nuclear monophagocytic system in the spleen, liver, and bone marrow, while the broad forms display tropism for smooth, cardiac, and striated muscle cells 2 .

The most probable explanation for this tropism involves molecular interactions on the cell surface between $T$. cruzi invader clones and the host tissues (cardiac muscle, myenteric plexus in the esophagus and colon, etc.). The initial idea of differential tissue tropism with an important role in the pathogenesis of Chagas disease gained new life when it was demonstrated that parasites with different genetic profiles can be found in different tissues (esophagus and heart) in the same patient 47 . Studies with dually infected mice showed a strong correlation between the parasite population profile (JG or Col1.7G2) and type of lesion in cardiac and rectal tissues 50 , as well as the persistence of one type (JG) in the chronic phase of the disease in a tissue previously infected with the other (CL-Brener clone) 51.
During the acute phase of Chagas disease, the parasites are present in different organs, but in the chronic phase they damage specific organs, manifesting genetic heterogeneity among the parasites isolated, which may explain the degree of tropism for different organs 52 . Both factors (host cell and parasite) appear to be involved in the infectivity and may form the basis for histotropism. Invasion of the non-phagocytic host cell by $T$. cruzi depends on parasite surface glycoproteins, and the ability of this infectivity varies among metacyclic trypomastigotes from different parasite populations. Such glycoproteins display differential activity in $\mathrm{Ca}^{2+}$ ion signaling 53,54.

The infective trypomastigote forms of $T$. cruzi are mobile due to the presence of a flagellum and have the capacity to infect numerous nucleated cells during the acute phase of the disease, establishing residence in the cell cytoplasm and differentiating into replicative amastigotes. Initiating communication between the infective forms of the parasite and mammalian cells requires contact between parasite ligands (soluble or around the membrane) and host cell receptors 55 .

Recognition by the host cell appears to be mediated by various parasite surface glycoproteins coded by multi-gene families, including gp82, gp90, and gp35/50, allowing interaction with different receptors and extracellular matrix molecules. Interaction between these ligands and their purported but unidentified receptors in the host cell appears to directly or indirectly affect the ability of gp 82 to engage its receptor and trigger the signaling mediated by $\mathrm{Ca}^{2+}$ ions. The levels of expression of parasite ligands may be an important determinant of tissue tropism 3 . This signaling mediated by $\mathrm{Ca}^{2+}$ ions is triggered by oligopeptidase $\mathrm{B}(\mathrm{OB})$ from the trypomastigote form, which activates phospholipase C (PLC) in the host cell and promotes the generation of inositol triphosphate (IP3) and the subsequent mobilization of $\mathrm{Ca}^{2+}$ ions from the intracellular reserves, such as the endoplasmic reticulum. Another entry pathway for the parasite is related to the release of bradykinin (active kinin) from the host cell kininogen, induced by the cruzipain present in the flagellar pouch of the trypomastigote, which binds to $B_{2} R$ receptors, stimulating the PLC to generate IP3 and elicit $\mathrm{Ca}^{2+}$ ions from the intracellular reserves 3 .

Recently, a conserved FLY (VTVXNVFLYNR) domain was described that is present in all members of the trans-sialidase/gp85 glycoprotein family located on the surface of trypomastigote forms that increase the efficiency of host cell invasion by binding to cytokeratin 18 from cultured epithelial cells. This process leads to its dephos- 
phorylation and reorganization, activating the ERK 1/2 signaling cascade, which culminates in a nine-fold increase in the number of parasites per cell 56 .

The increase in the concentration of $\mathrm{Ca}^{2+}$ ions released in the host cell cytoplasm is accompanied by a quinesin-dependent local recruitment of lisosomes towards the cell plasma membrane through microtubules that merge with the membrane to form the lysosome-derived parasitophorous vacuole 57. Exposure of trypomastigotes to the acid environment of the lysosomal vacuole facilitates the activity of the T. cruzi pore-forming molecule (Tc-Tox), which facilitates the rupture of the vacuole. Additionally, the low $\mathrm{pH}$ acts as an important activator for trypomastigotes to differentiate into amastigotes, which begins inside the vacuole and ends in the host cell cytoplasm ${ }^{3}$.

After the parasitophorous vacuole ruptures, trypomastigotes are released into the cytoplasm and conclude the differentiation into amastigote forms, which begin to divide approximately 24 hours after infection ${ }^{3}$. These forms multiply by simple binary division every 12 hours for a total of nine generations, differentiate into trypomastigotes by the elongation process, and are released into the intercellular space due to the rupture of the host cell 2, infecting neighboring cells or reaching the bloodstream, where they can infect cells from other tissues or be ingested by the insect vector and complete the life cycle. Only the trypomastigote forms are capable of rupturing the vacuole membrane, while the epimastigote forms are destroyed inside it. It has been demonstrated that the membrane surrounding the parasitophorous vacuole differs according to the parasite's developmental phase 57 .

Southern blot DNA analysis of macrophage lineages transfected with $T$. cruzi trypomastigote forms, once inside the host cell, showed band patterns formed by hybridization with the minicircle kDNA probe, thus demonstrating horizontal transfer of sequences of this molecule that are integrated into the host cell DNA by natural infection. Immunofluorescence assays suggested that the integration of kDNA into the genome of macrophage clone lineages leads to alteration of the host cell expression. Thus, kDNA integration sites associated with modifications in the host genome may represent a critical biological element in the host-pathogen interactions leading to the chronic clinical manifestations of Chagas disease 58 .

According to Teixeira et al. 59, persistent, lifelong chronic infection in the Chagas disease patient is sufficient to allow the occurrence of new kDNA integration events in multiple genome sites. In some patients, accumulated mutations caused by insertion in the host genome may trigger the immune system's rejection mechanism in the heart and other organs, leading to a gradual increase in the number of host protein alterations.

The nature of the variability of Chagas disease in humans probably results from the variation in the immune response efficiency in different individuals; for example, efficient immune responses control the parasite level, limiting the tissue damage, while inefficient responses fail to adequately control the parasite burden, thus leading to persistent inflammatory reactions and a more severe clinical condition 60 .

The cellular immune response is an important factor in the control of T. cruzi in all stages of the disease, and an immune imbalance can result in increased blood and tissue parasitism 61 . The correlation between the frequency and intensity of the tissue inflammatory process in the presence of the parasite can be observed especially in cases of advanced megaesophagus. This was observed by Lages-Silva et al. 62 in $80.8 \%$ of the tissues examined in megaesophagus, where they found an association between the presence of T. cruzi, its antigens, or genomic fragments detected by immunohistochemistry and PCR. However, these same authors also observed the parasite's presence in tissues without inflammation, which in such cases may be due to recent invasion in which there was still no focal inflammatory response or no degree of host immunosuppresion 63 .

According to one hypothesis, immunosuppressive T. cruzi excreted-secreted antigens (ESA) are involved, serving to maintain chronic infections, acting as regulatory (activation/inhibition) factors for the host immune cells (B and/or Tcells, macrophages, and dendritic cells). Such antigens are molecules belonging to the glutathione S-transferase (GST) super-family, or socalled Tc52, which is expressed by intracellular amastigotes. Elevated levels of this protein in the bloodstream of mice experimentally infected with T. cruzi occur during the acute phase of the disease and are associated with the decreased Tcell response to the mitogen 64 .

Under experimental conditions, Tc52 appears to be relatively silent, immunologically, during the early acute phase. This protein's molecule presents discrete domains that can minimize its antigenicity, whereby it fails to stimulate significant antibody levels and lymphocyte proliferation. A $28 \mathrm{kDa}$ fragment (Tc28k) located in the carboxy-terminal portion of the Tc52 protein was identified with the capacity to inhibit T-cell activation 64 . This peptide is related to low secretion of IL- 2 and IFN- $\gamma$ and may allow the parasites to 
escape the immune surveillance and grow unimpeded due to the blockade of normal immune responses. In such cases, the host can become susceptible to opportunistic infections 64 .

Another proposed mechanism for the parasite's action on the host immune system is apoptosis, by means of the release of factors that kill the immune system's cells by activating the programmed cell death machinery. A principal surface glycoconjugate from T. cruzi, GIPL, has been shown to induce macrophage apoptosis through its lipid ceramide domain 65 . Paradoxically, there is evidence that the parasites can inhibit host cell apoptosis, such that parasitederived molecules can interfere in cell growth. For example, T. cruzi trans-sialidase can impede nerve cell apoptosis, since it can activate expression of the $b c l-2$ gene, leading to the protection of rat pheochromocytoma PC12 cells (a lineage that displays various neuronal characteristics) against apoptosis induced by growth factor deprivation 65 . It is thus reasonable to suggest that among the molecules released by the parasite, those conferring a selective advantage to it represent potential targets for the development of treatment strategies to moderate the host immune system dysfunction 65 .

Although the abundant heterogeneous glycoproteins on the surface of T. cruzi trypomastigotes possess affinities with extracellular matrix proteins from mammalian cells and thus guarantee access to the host cell during the acute phases of infection, it is still not clear which signaling pathways induced by the parasite are integrated to coordinate the invasion, support intracellular replication, or influence tissue tropism 3 .

\section{Chagas disease megaesophagus and its association with esophageal carcinoma}

Megaesophagus is one of the clinical manifestations of the digestive form of Chagas disease, occurring in some $2 \%$ to $8.8 \%$ of patients in the chronic phase in Central Brazil 66, developing in patients infected with T. cruzi clones that present preferential tropism for esophageal tissue muscle cells. One of the serious late consequences of megaesophagus is the increased risk of these patients developing esophageal carcinoma 49. Our research group has studied these diseases with a specific focus on potential molecular markers for early diagnosis of carcinoma of the esophagus in patients with chagasic megaesophagus, as well as a possible association between $T$. cruzi genetic diversity and megaesophagus.

Megaesophagus occurs as a consequence of achalasia, characterized by the destruction or absence of intramural nerve plexi in the esophagus due to T. cruzi infection and leading to loss of peristalsis in the esophageal body and the lack of opening of the lower esophageal sphincter in response to swallowing, thereby causing esophageal stasis (stagnated food passage), accentuated initial discoordination, and progressive dilatation and decreased contractile capacity of the organ. Chagas disease is the only proven etiological factor for megaesophagus. However, the cause of megaesophagus is unknown in the rest of the world and has been associated with a viral etiology, genetic influence (association with HLA), and autoimmune processes 67,68,69. Dysphagia (difficulty in swallowing) is the most prominent clinical symptom of megaesophagus and generally shows a long evolution, installing progressively, initially for solid foods, later for semi-solids, and later also for liquids 49 .

Patients with megaesophagus display mucosal inflammation due to esophageal stasis and the action of bacteria present in stagnated foods, growing in suspension in the lumen. Such factors can favor the development of epithelial dysplasia, culminating in chronic esophagitis affecting the entire esophageal mucosa. This may be the first step in the development of squamous-cell esophageal carcinoma, which is 33 times more frequent in these patients than in the general population 70 and whose incidence varies from $2 \%$ to $8.6 \% 49,71$.

Fein et al. 72 suggested the action of the microbiota on the esophagus based on an experimental study of esophageal carcinogenesis. Later, patients with advanced megaesophagus were shown to have a high concentration of bacteria in the stasis liquid with the capacity to reduce dietary nitrates into nitrites and N-nitrous compounds with DNA mutagenic properties. Bacterial concentration was correlated with the degree of esophageal dilatation 73,74 . Chronic stasis thus favored the prolonged persistence of mutagenic compounds in contact with the mucosa, thus explaining the increased risk of esophageal cancer in patients with megaesophagus 74 .

Squamous-cell carcinoma of the esophagus has a multifactor etiology, including environmental exposure, dietary habits, chronic esophagitis, cultural influences, and possibly genetic predisposition 75. Esophageal carcinoma generally affects patients with a long history of dysphagia, with late diagnosis, when the symptoms have remained disguised. This delay allows much greater tumor growth, to the point of obstructing the dilated esophagus, leading to a poor prognosis. Early diagnosis of the cancer can be aided by routine endoscopic examination of patients with megaesophagus 49 . 
Although research on genetic alterations in chagasic megaesophagus is still limited, one study reported a mutation in the TP53 tumor suppressor gene and increased expression of its protein in the mucosa of patients with advanced chagasic megaesophagus and in tumor mucosa associated with advanced megaesophagus, indicating the presence of mutant $\mathrm{p} 53$ protein and propensity to malignant transformation 76 . Chino et al. 77 also observed increased expression of p53 protein both in carcinoma associated with idiopathic achalasia and in dysplasia, suggesting that dysplastic alterations in patients with advanced achalasia may be related to increased risk of tumor development. These authors also detected loss of p16 protein expression, which together with p53 participates in cell cycle regulation in the invasive parts of the carcinoma and in situ carcinoma in relation to the areas with dysplasia, hyperplasia, and normal epithelium.

Our research group recently described the occurrence of aneuploidies (principally trisomies) in chromosomes 7, 11, and 17 and deletion of the TP53 gene in the esophageal mucosa in individuals with chagasic megaesophagus with no history of cancer, and frequent increased involvement of these alterations in patients with esophageal carcinoma 78 . Although limited, these data suggest that such alterations may be involved in the initial phases of malignant transformation, increasing the risk of developing squamous-cell carcinoma of the esophagus in this type of disease.

\section{Final remarks}

Although Chagas disease was discovered approximately nine decades ago, its pathogenesis and the mechanisms in the parasite-host relationship are still not well understood. It is known that the pathogenesis of megaesophagus may be related to host characteristics as well as those of different T. cruzi clones 62 .

Throughout these nine decades, much has been discovered on the biological characteristics involving Chagas disease, such as: T. cruzi genetic diversity and the mechanisms of the parasite's entry into the host cell as regards the signaling pathways involving surface molecules on both the parasite and host cell, allowing the parasite to reach the cytoplasm and to replicate 3 ; factors released by the parasite that elicit different inflammatory responses, that may or may not lead to host cell apoptosis 64,65; mechanisms in the integration of $T$. cruzi kDNA fragments into the host cell genome, functioning as mutations that lead to changes in the host cell phenotype, evoking the immune system's rejection of cells containing the mixture of the expression of its proteins with those of the inserted kDNA 3 ; and evidence that different clones present differential tissue tropism, depending on the biological form of the parasite during infection ${ }^{2}$.

Due to the intraspecific diversity of $T$. cruzi populations isolated from patients presenting the same clinical form of Chagas disease, at present it is still not possible to establish an association between the parasite's genotype and the manifestation of the disease. It will be necessary to search for other genetic markers in the nuclear genome or kDNA in order to better characterize the role of $T$. cruzi in the pathogenesis of Chagas disease 48 . 


\section{Resumo}

O Trypanosoma cruzi, agente etiológico da doença de Chagas, apresenta elevado grau de variabilidade genética intra-específica, com possíveis implicações na forma clínica da doença, como o desenvolvimento de cardiopatia, do megaesôfago e do megacólon de forma isolada ou em associação. Este tropismo tecidual envolvido na patogênese da doença não está totalmente esclarecido. Assim, nesta revisão são abordados alguns aspectos referentes à diversidade genética dos parasitas isolados, às formas clínicas da doença de Chagas, ao processo de infecção do parasita na célula hospedeira e resposta imune. Outros aspectos também são enfocados, como os fatores imunossupressivos liberados pelo parasita que atuam na regulação das respostas imunes, a inibição da apoptose da célula hospedeira, assim como da patogênese do megaesôfago chagásico que pode estar relacionada à interação hospedeiroparasita e sua associação com risco aumentado para o desenvolvimento do carcinoma epidermóide do esôfago. Porém, apesar dos avanços no entendimento desta doença, ainda não é possível estabelecer o verdadeiro perfil da variabilidade genética do parasita com a forma clínica da doença de Chagas.

Acalasia Esofágica; Trypanosoma cruzi; Variação (Genética); Doença de Chagas

\section{References}

1. Wendel S, Brener Z, Camargo ME, Rassi A. Chagas disease - American trypanosomiasis: the impact on transfusion and clinical medicine. In: International Society Blood Transfusion - ISBT BRAZIL' 92. São Paulo: International Society of Blood Transfusion; 1992. p. 13-29.

2. Lana M, Tafuri WL. Trypanosoma cruzi e doença de Chagas. In: Neves DP, organizador. Parasitologia humana. São Paulo: Editora Atheneu; 2000. p. 7396.

3. Burleigh BA, Woolsey AM. Cell signaling and Trypanosoma cruzi invasion. Cell Microbiol 2002; 4:701-11.

4. Buscaglia CA, Di Noia JM. Trypanosoma cruzi clonal diversity and the epidemiology of Chagas' disease. Microbes Infect 2003; 5:419-27.

5. Prata A. Clinical and epidemiological aspects of Chagas disease. Lancet Infect Dis 2001; 1:92-100

6. Secretaria de Vigilância em Saúde, Ministério da Saúde. Doença de Chagas aguda relacionada à ingestão de caldo de cana em Santa Catarina. http://www.anvisa.gov.br/divulga/noticias/ 2005/240305_nota.pdf (accessed on 17/Oct/2006).

\section{Contributors}

F. S. Manoel-Caetano participated in the literature search and drafting of the manuscript. A. E. Silva collaborated in the reading and review of the manuscript, inserting modifications in the paper's structure and content, based on the bibliographic references utilized.
7. Coura JR, Barretto TV, Naranjo MA. Ataque de populações humanas por triatomíneos silvestres no Amazonas: uma nova forma de transmissão da infecção chagásica. Rev Soc Bras Med Trop 1994; 27:251-3.

8. Dias JCP. Notas sobre o Trypanosoma cruzi e suas características bio-ecológicas, como agente de enfermidades transmitida por alimentos. Rev Soc Bras Med Trop 2006; 39:370-3.

9. Cortez M, Silva MR, Neira I, Ferreira D, Sasso GRS, Luquetti AO, et al. Trypanosoma cruzi surface molecule gp90 down-regulates invasion of gastric mucosal epithelium in orally infected mice. Microbes Infect 2006; 8:36-44.

10. Camandaroba ELP, Lima CMP, Andrade SG. Oral transmission of Chagas disease: importance of Trypanosoma cruzi biodeme in the intragastric experimental infection. Rev Inst Med Trop São Paulo 2002; 44:97-103. 
11. Pinto AYN, Harada GS, Valente VC, Abud JEA, Gomes FS, Souza GCR, et al. Acometimento cardíaco em pacientes com doença de Chagas aguda em microepidemia familiar, em Abaetetuba, na Amazônia Brasileira. Rev Soc Bras Med Trop 2001; 34:413-9.

12. Souto Jr. JV, Ribeiro MAA. Doença de Chagas. http://www.fozdoiguacu.pr.gov.br/notícias/ link33.htm (accessed on 07/May/2005).

13. World Health Organization. Chagas. http://www. who.int/ctd/chagas/disease.htm (accessed on 09/ Oct/2006).

14. Coura JR. Tripanossomose, doença de Chagas. Ciênc Cult (São Paulo) 2003; 55:30-3.

15. Universidade Federal do Rio Grande do Sul. Trypanosoma cruzi. http://www.ufrgs.br/para-site/ Imagenatlas/Protozoa/Trypanosomacruzi.htm (accessed on 28/Jun/2007).

16. Macedo AM, Pena SDJ. Genetic variability of Trypanosoma cruzi: implications for the pathogenesis of Chagas disease. Parasitol Today 1998; 14:119-24.

17. Oliveira RB, Troncon LEA, Dantas RO, Meneghelli UG. Gastrointestinal manifestations of Chagas' disease. Am J Gastroenterol 1998; 93:884-9.

18. Macedo AM, Machado CR, Oliveira RP, Pena SDJ. Trypanosoma cruzi: genetic structure of populations and relevance of genetic variability to the pathogenesis of Chagas disease. Mem Inst Oswaldo Cruz 2004; 99:1-12.

19. Andrade SG. Trypanosoma cruzi: clonal structure of parasite strains and the importance of principal clones. Mem Inst Oswaldo Cruz 1999; 94 Suppl 1:185-7.

20. Blanco A, Montamat EE. Genetic variation among Trypanosoma cruzi populations. J Exp Zool 1998; 282:62-70.

21. Miles MA, Toye PJ, Oswald SC, Godfrey DG. The identification by isoenzyme patterns of two distinct strain-groups of Trypanosoma cruzi, circulating independently in a rural area of Brazil. Trans $\mathrm{R}$ Soc Trop Med Hyg 1977; 71:217-25.

22. Miles MA, Lanham SM, Souza AA, Povoa M. Further enzymic characters of Trypanosoma cruzi and their evaluation for strain identification. Trans R Soc Trop Med Hyg 1980; 74:221-37.

23. Tibayrenc M, Ward P, Moya A, Ayala FJ. Natural populations of Trypanosoma cruzi, the agent of Chagas' disease, have a complex multiclonal structure. Proc Natl Acad Sci USA 1986; 83:115-9.

24. Tibayrenc M, Ayala F. Isozyme variability in Trypanosoma cruzi, the agent of Chagas disease: genetic, taxonomical and epidemiological significance. Evolution 1988; 42:277-92.

25. Revollo S, Oury B, Laurent JP, Barnabé C, Quesney V, Carriere V, et al. Trypanosoma cruzi: impact of clonal evolution of the parasite on its biological and medical properties. Exp Parasitol 1998; 89:309.

26. Andrade V, Brodoskyn C, Andrade SG. Correlation between isoenzyme patterns and biological behavior of different strains of Trypanosoma cruzi. Trans R Soc Trop Med Hyg 1983; 77:796-9.

27. Souto RP, Fernandes O, Macedo AM, Campbell DA, Zingales B. DNA markers define two major phylogenetic lineages of Trypanosoma cruzi. Mol Biochem Parasitol 1996; 83:141-52.
28. Recommendations from satellite meeting. Mem Inst Oswaldo Cruz 1999; 94 Suppl 1:1-6.

29. Brisse S, Barnabé C, Tibayrenc M. Identification of six Trypanosoma cruzi phylogenetic lineages by random amplified polymorphic DNA and multilocus enzyme. Int J Parasitol 2000; 30:35-44.

30. Henriksson J, Dujardin J, Barnabe C, Brisse S, Timperman G, Venegas J, et al. Chromosomal size variation in Trypanosoma cruzi is mainly progressive and is evolutionarily informative. Parasitology 2002; 124:277-86.

31. Gomes ML, Macedo AM, Vago AR, Pena SDJ, Galvão LMC, Chiari E. Trypanosoma cruzi: optimization of polymerase chain reaction for detection in human blood. Exp Parasitol 1998; 88:28-33.

32. D'Ávila DA, Gontijo ED, Lages-Silva E, Meira WSF, Chiari E, Galvão LMC. Random amplified polymorphic DNA profiles of Trypanosoma cruzi isolates from chagasic patients with different clinical forms. Parasitol Res 2006; 98:455-61.

33. Gomes ML, Macedo AM, Pena SD, Chiari E. Genetic relationships between Trypanosoma cruzi strains isolated from chronic chagasic patients in southern Brazil as revealed by RAPD and SSR-PCR analysis. Acta Trop 1998; 69:99-109.

34. Breniere S, Bosseno M, Telleria J, Bastrenta B, Yacsik N, Noireau F, et al. Different behavior of two Trypanosoma cruzi major clones: transmission and circulation in young Bolivian patients. Exp Parasitol 1998; 89:285-95.

35. Kawashita S, Sanson G, Fernandes O, Zingales B, Briones M. Maximum-likelihood divergence date estimates based on rRNA gene sequences suggest two scenarios of Trypanosoma cruzi intraspecific evolution. Mol Biol Evol 2001; 18:2250-9.

36. Fernandes O, Santos SS, Junqueira ACV, Jansen AM, Cupolillo E, Campbel DA, et al. Populational heterogeneity of Brazilian Trypanosoma cruzi isolates revealed by the mini-exon and ribosomal spacers. Mem Inst Oswaldo Cruz 1999; 94 Suppl 1:195-7.

37. Freitas JM, Lages-Silva E, Crema E, Pena SDJ, Macedo AM. Real time PCR strategy for the identification of major lineages of Trypanosoma cruzi directly in chronically infected human tissues. Int J Parasitol 2005; 35:411-7.

38. Miles MA, Cedillos RA, Povoa MM, Souza AA, Prata A, Macedo V. Do radically dissimilar Trypanosoma cruzi strains (zymodemes) cause Venezuelan and Brazilian forms of Chagas disease? Lancet 1981; 1:1338-40

39. Lauria-Pires L, Bogliolo AR, Teixeira ARL. Diversity of Trypanosoma cruzi stocks and clones derived from Chagas disease patients. Exp Parasitol 1996; 82:182-90.

40. Morel C, Chiari E, Camargo P, Mattei DM, Romanha AJ, Simpson J. Strains and clones of Trypanosoma cruzi can be characterized by pattern of restriction endonuclease products of kinetoplast DNA minicircles. Proc Natl Acad Sci USA 1980; 77:6810-4.

41. Shlomai J. The assembly of kinetoplast DNA. Parasitol Today 1994; 10:341-6. 
42. Teixeira ARL, Argañaraz ER, Freitas Jr. LH, Lacava ZGM, Santana JM, Luna H. Possible integration of Trypanosoma cruzi kDNA minicircles into the host cell genome by infection. Mutat Res 1994; 305:197209.

43. Junqueira ACV, Degrave W, Brandão A. Minicircle organization and diversity in Trypanosoma cruzi populations. Trends Parasitol 2005; 21:270-2.

44. Pena SD, Barreto G, Vago AR, De Marco L, Reinach FC, Dias Neto E, et al. Sequence-specific "gene signatures" can be obtained by PCR with single specific primers at low stringency. Proc Natl Acad Sci USA 1994; 91:1946-9.

45. Vago AR, Macedo AM, Oliveira RP, Andrade LO, Chiari E, Galvão LM, et al. kDNA signatures of Trypanosoma cruzi strains obtained directly from infected tissues. Am J Pathol 1996; 149:2153-9.

46. Vago AR, Macedo AM, Adad S, Reis DA, CorrêaOliveira R. PCR detection of Trypanosoma cruzi DNA in esophageal tissues of patients with chronic digestive Chagas' disease. Lancet 1996; 348:891-2.

47. Vago AR, Andrade LO, Leite AA, d'Ávila-Reis D, Macedo AM, Adad SJ, et al. Genetic characterization of Trypanosoma cruzi directly from tissues of patients with chronic Chagas disease: differential distribution of genetic types into diverse organs. Am J Pathol 2000; 156:1805-9.

48. Lages-Silva E, Ramírez LE, Pedrosa AL, Crema E, Galvão LMC, Pena SDJ, et al. Variability of kinetoplast DNA gene signatures of Trypanosoma cruzi II strains from patients with different clinical forms of Chagas' disease in Brazil. J Clin Microbiol 2006; 44:2167-71.

49. Pinotti HW, Domene CE, Cecconello I, Zilberstein B. Megaesôfago chagásico. In: Coelho JCU, org. Aparelho digestivo. Rio de Janeiro: Editora Medsi; 1996. p. 61-7.

50. Andrade LO, Machado CRS, Chiari E, Pena SDJ, Macedo AM. Differential tissue distribution of diverse clones Trypanosoma cruzi in infected mice. Mol Biochem Parasitol 1999; 100:163-72.

51. Franco DJ, Vago AR, Chiari E, Meira FCA, Galvão LMC, Machado CRS. Trypanosoma cruzi: mixture of two populations can modify virulence and tissue tropism in rat. Exp Parasitol 2003; 104:54-61.

52. Vera-Cruz JM, Magallón-Gastelum E, Grijalva G, Rincón AR, Ramos-Garcia C, Armendáriz-Borunda J. Molecular diagnosis of Chagas' disease and use of an animal model to study parasite tropism. Parasitol Res 2003; 89:480-6.

53. Ruiz RC, Favoreto Jr. S, Dorta ML, Oshiro MEM, Ferreira AT, Manque PM, et al. Infectivity of Trypanosoma cruzi strains is associated with differential expression of surface glycoproteins with differential $\mathrm{Ca}^{2}+$ signaling activity. Biochem J 1998; 330:505-11.

54. Acosta-Serrano A, Almeida IC, Freitas-Junior LH, Yoshida N, Schenkman S. The mucin-like glycoprotein super-family of Trypanosoma cruzi: structure and biological roles. Mol Biochem Parasitol 2001; 114:143-50.

55. Herrera EM, Ming M, Ortega-Barria E, Pereira ME. Mediation of Trypanosoma cruzi invasion by heparin sulphate on host cells and penetrin counterreceptors on the trypanosomes. Mol Biochem Parasitol 1994; 65:73-83.
56. Magdesian MH, Tonelli RR, Fessel MR, Silveira MS, Schumacher RI, Linden R, et al. A conserved domain of the gp85/trans-sialidase family activates host cell extracellular signal-regulated kinase and facilitates Trypanosoma cruzi infection. Exp Cell Res 2007; 313:210-8.

57. Carvalho TMU, Souza W, Coimbra ES. Internalization of components of the host cell plasma membrane during infection by Trypanosoma cruzi. Mem Inst Oswaldo Cruz 1999; 94 Suppl 1:143-7.

58. Simões-Barbosa A, Barros AM, Nitz N, Argañaraz ER, Teixeira ARL. Integration of Trypanosoma cruzi kDNA minicircle sequence in the host genome may be associated with autoimmune serum factors in Chagas disease patients. Mem Inst Oswaldo Cruz 1999; 94 Suppl 1:249-52.

59. Teixeira A, Rumjanek F, Silva LM. Na caça do DNA invasor. Ciênc Hoje 2005; 36:6-9.

60. Tarleton RL. Parasite persistence in the aetiology of Chagas disease. Int J Parasitol 2001; 31:550-4.

61. Sartori AM, Sotto MN, Braz LMA, Oliveira-Junior OC, Patzina RA, Barone AA, et al. Reactivation of Chagas' disease manifested by skin lesions in a patient with AIDS. Trans R Soc Med Hyg 1999; 93:6312.

62. Lages-Silva E, Crema E, Ramirez LD, Macedo AM, Pena SD, Chiari E. Relationship between Trypanosoma cruzi and human chagasic megaesophagus: blood and tissue parasitism. Am J Trop Med Hyg 2001; 65:435-41.

63. Ouaissi A, Ouaissi M, Tavares J, Cordeiro-da-Silva A. Host cell phenotypic variability induced by trypanosomatid-parasite-released immunomodulatory factors: physiopathological implications. J Biomed Biotechnol 2004; 2004:167-74.

64. Freire-de-Lima CG, Nunes MP, Corte-Real S, Soares MP, Previato JO, Mendonça-Previato L, et al. Proapototic activity of a Trypanosoma cruzi ceramide-containing glycolipid turned on in host macrophages by IFN- $\gamma$. J Immunol 1998; 161:490916.

65. Chuenkova MV, Furnari FB, Cavenee WK, Pereira MA. Trypanosoma cruzi trans-sialidase: a potent and specific survival factor for human Schwann cells by means of phosphatidylinositol 3-kinase/Akt signaling. Proc Natl Acad Sci USA 2001; 98:9936-41.

66. Castro C, Macedo V, Resende JM, Prata A. Estudo radiológico longitudinal do esôfago, em área endêmica de doença de Chagas, em um período de seis anos. Rev Soc Bras Med Trop 1992; 25:225-30.

67. Storch W, Eckardt VF, Wienbeck M, Eberl T, Auer PG, Hecker A, et al. Autoantibodies to Auerbach's plexus in achalasia. Cell Mol Biol (Noisy-le-grand) 1995; 41:1033-8.

68. Raymond L, Lanch B, Shamji FM. Inflammatory aetiology of primary oesophageal achalasia: an immunohistochemical and ultrastructural study of Auerbach's plexus. Histopathology 1999; 35:44553.

69. Moses PL, Ellis LM, Anees MR. Antineuronal antibodies in idiopathic achalasia and gastro-oesophageal reflux disease. Gut 2003; 52:629-36.

70. Loviscek LF, Cenoz MC, Badaloni AE, Agarinakazato O. Early cancer in achalasia. Dis Esophagus 1998; 11:239-47. 
71. Brücher BLDM, Stein HJ, Bartels H, Feussner H, Siewert JR. Achalasia and esophageal cancer: incidence, prevalence, and prognosis. World J Surg 2001; 25:745-9.

72. Fein M, Fuchs KH, DeMeester TM, Peters JH, Wimann D, Weig M. Evaluation of the intestinal microflora in the rat model for esophageal adenocarcinoma. Dis Esophagus 2000; 13:39-43.

73. Pajecki D, Zilberstein B, Santos MAA, Ubriaco JA, Quintanilha AG, Cecconello I, et al. Megaesophagus microbiota: a qualitative and quantitative analysis. J Gastrointest Surg 2002; 6:723-9.

74. Pajecki D, Zilberstein B, Santos MAA, Quintanilha AG, Cecconello I, Gama-Rodrigues J. Microbiota do megaesôfago e carcinogênese. Arq Gastroenterol 2003; 40:16-9.
75. Messmann H. Squamous cell cancer of the oesophagus. Best Pract Res Clin Gastroenterol 2001; 15:249-65.

76. Safatle-Ribeiro AV, Ribeiro Jr. U, Sakai P, Clarke MR, Fylyk SN, Ishioka S, et al. Integrated p53 histopathologic/genetic analysis of premalignant lesions of the esophagus. Cancer Detect Prev 2000; 24:13-23.

77. Chino O, Kijima H, Shimada H, Nishi T, Tanaka H, Oshiba G, et al. Clinicopathological studies of esophageal carcinoma in achalasia: analysis of carcinogenesis using histological and immunohistochemical procedures. Anticancer Res 2000; 20:3717-22.

78. Manoel-Caetano FS, Borim AA, Caetano A, Cury PM, Silva AE. Cytogenetic alterations in chagasic achalasia compared to esophageal carcinoma. Cancer Genet Cytogenet 2004; 149:17-22.

Submitted on $23 / \mathrm{Jan} / 2007$

Final version resubmitted on $05 / \mathrm{Jul} / 2007$

Approved on 13/Jul/2007 